\title{
Çokamaçlı Kesirli Programlama Problemleri için Q- Taylor Metodu
}

\author{
Adem C. Cevikel ${ }^{1 *}$, Muttalip Ozavsar ${ }^{2}$ \\ 1 Yıldız Teknik Üniversitesi, Eğitim Fakültesi, Matematik Eğitimi Bölümü, İstanbul, Türkiye (ORCID: 0000-0002-7359-3156) \\ ${ }^{2}$ Yıldız Teknik Üniversitesi, Fen Edebiyat Fakültesi, Matematik Bölümü, İstanbul, Türkiye (ORCID: 0000-0001-2345-6789)
}

(İlk Geliş Tarihi 14 Mart 2019 ve Kabul Tarihi 12 Mayıs 2019)

(DOI: $10.31590 /$ ejosat.540089)

ATIF: Cevikel, A. C. ve Ozavsar, M. (2019). Çokamaçlı Kesirli Programlama Problemleri için Q- Taylor Metodu. Avrupa Bilim ve Teknoloji Dergisi, (16), 26-31.

\section{Özet}

Bu çalışmada, çok amaçlı lineer kesirli programlama problemlerinin (ÇALKPP) çözümleri için uygun bölgedeki herbir kesirli amaç fonksiyonunun optimal noktalarında amaç fonksiyonlarının birinci dereceden $q$-Taylor seri açılımları sunulmuştur. Q-Analizde, $q$ Taylor serisi $q$-Türevlerine göre bir fonksiyonun $q$-Serisine genişlemesidir. ÇALKPP problemi, kendisine denk olan çok amaçlı lineer programlama problemlerini (ÇALPP) problemine indirgendi. Amaç fonksiyonlarının ağırlıklarının eşit olduğu kabulü altında ÇALPP çözüldü. Böylece problem tek amaca indirgenmiş oldu. Sunulan metot ile elde edilen çözümler etkin çözümlerdir. Bu sayede ÇALPP problemlerinin çözümündeki karmaşıklık giderilmiş olundu ve sunulan metodun etkinliğini göstermek için bir problem üzerinde uygulanmasi yapıld1.

Anahtar Kelimeler: Çok amaçlı programlama, Çok amaçlı lineer kesirli programlama, Q-Analiz, Q-Taylor serisi.

\section{Q-Taylor Method for Multiobjective Fractional Programming Problem}

\begin{abstract}
In this work, we have proposed a solution to Multi Objective Lineer Fractional Programming Problem (MOLFPP) by using the firstorder q-Taylor expansion of these objective functions at optimal points of each fractional objective functions in feasible region. In qcalculus, q-Taylor series is a q-series expansion of a function with respect to q-derivatives. MOFPP reduces to an equivalent Multi Objective Linear Programming Problem (MOLPP). The resulting MOLPP is solved assuming that weights of these objective functions are equal and considering the sum of the these objective functions. Thus, the problem is reduced to a single objective. The proposed solution to MOFPP always yields efficient solution. Therefore, the complexity in solving MOFPP has reduced and to show the efficiency of the q-Taylor series method, we applied the method to a problem.
\end{abstract}

Key words: Multiobjective programming, Multiobjective linear fractional programming, Q-Calculus, Q-Taylor series.

\footnotetext{
* Sorumlu Yazar: Yıldız Teknik Üniversitesi, Eğitim Fakültesi, Matematik Eğitimi Bölümü, İstanbul, Türkiye, ORCID: 0000-0002-7359-3156, acevikel@yildiz.edu.tr
} 


\section{Introduction}

The fractional programming problem (FPP), which has been used as an important planning tool in recent years, is applied to different disciplines such as engineering, business, finance, economics, etc. FP is generally used for modeling real life problems with one or more objectives such as profit/cost, inventory/sales, actual cost/ standart cost, output/employee etc.

In the literature, different approaches appear to solve different models of Fractional Programming Problem (FPP). They are that FPP can be optimised easily. But, in the great scale decision problems, there is more than one objective, which must be satisfied at the same time as possible. However, most of these are fractional objectives. It is diffucult to talk about the optimal solutions of these problems. The solutions searched for these problems are weak efficient or strong efficient.

The multiobjective fractional programming problem (MOFP) is considered in the literature. [2, 5, 6, 8, 9]. Multiobjective Linear Fractional Programming Problem (MOLFPP) pose some computational difficulties, so they are converted into single objective FPPs and then solved using the metod of Bitran and Novaes [1] or Charnes and Cooper [3].

In this paper, we proposed a solution to MOFPP using the first order q -Taylor polynomial series method at an optimal point of each fractional objective function in feasible region.

\section{Preliminaries}

Definition: If the numerator and denominator in the objective function as well as the constraints are linear, we have a linear fractional programming problem (LFPP) as follows:

$$
\begin{gathered}
\text { Optimize } \frac{c x+\alpha}{d x+\beta}, \\
\text { s.t. } x \in S=\left\{x \mid A x\left(\begin{array}{l}
\leq \\
= \\
\geq
\end{array}\right) b, x \geq 0\right\}
\end{gathered}
$$

where $A$ is a real $m \times n$ matrix, $b \in R^{m}, x \in R^{n}$ and $S$ is a nonempty and bounded set. For some values of $x, d x+\beta$ may be equal to zero. To avoid such cases, is generally set to be greater than zero.

Charnes and Cooper [3] showed that if the denominator is constant in sign on the feasible region, the LFPP can be optimized by solving a linear programming problem. However, in many applications, there are two or more conflicting objective functions which are relevant, and some compromise must be bought between them. Such types of problems are inherently multiobjective linear fractional programming problems and can be written as:

$$
\begin{aligned}
& \text { Optimize } \mathrm{Z}_{k}(x)=\frac{c_{k} x+\alpha_{k}}{d_{k} x+\beta_{k}}, k=1, \ldots, K \\
& \text { s.t. } x \in S=\left\{x \mid A x\left(\begin{array}{l}
\leq \\
= \\
\geq
\end{array}\right) b, x \geq 0\right\}
\end{aligned}
$$

where $S, A, b$ and $x$ are as defined in problem (2.1), and $\forall x \in S, d_{k} x+\beta_{k}>0(\mathrm{k}=1, \ldots, \mathrm{K})$.

Definition: Let $q \in(0,1)$. A $q$-natural number $[n]_{q}$ is given by

$$
[n]_{q}:=\frac{1-q^{n}}{1-q}, n \in N
$$

The factorial of a $q$-number $[n]_{q}$ is defined by

$$
[0]_{q} !:=1,[n]_{q} !:=[n]_{q} \cdot[n-1]_{q} \ldots[1]_{q}
$$

$q$-Pachammer symbol is: 


$$
(z-a)^{(0)}:=1, \quad(z-a)^{(0)}:=\prod_{i=0}^{k-1}\left(z-a q^{i}\right), k \in N .
$$

Definition: : Let $f: D \subset R \rightarrow R$ be a continuous function. In $q$-calculus [4], the $q$-derivative of $f$ is defined by the operatör

$$
\begin{gathered}
D_{q}(f(x)):=\frac{f(q \cdot x)-f(x)}{(q-1) \cdot x}, x \neq 0, q \neq 1, \\
D_{q}(f(0)):=\lim _{x \rightarrow 0}\left(D_{q}(f(x))\right) .
\end{gathered}
$$

Notice that $f$ should be continuous at the point $q \cdot x$ for all $x \in D$ and $q \in(0,1)$.

Definition: Let $f: D \subset R \rightarrow R$ be a multivariable continous function, the $q$-partial derivative of $f$ is given by

$$
\begin{aligned}
& D_{q x_{i}} f(x):=\frac{f\left(Q_{i}(x)\right)-f(x)}{(q-1) \cdot x_{i}}, x_{i} \neq 0, \\
& x:=\left(x_{1}, x_{2, \ldots .,} x_{n}\right) \in D, i=1, \ldots, n \\
& \left.D_{q x_{i}} f(x)\right|_{x_{i}=0}=\lim _{x_{i} \rightarrow 0}\left(D_{q x_{i}}(f(x))\right.
\end{aligned}
$$

Where $Q_{i}$ acting on $R^{n}$ is an operator defined by

$$
Q_{i}\left(x_{1}, x_{2}, \ldots x_{i}, \ldots, x_{n}\right):=\left(x_{1}, x_{2}, \ldots, q \cdot x_{i}, \ldots, x_{n}\right)
$$

Lemma: Operators $D_{q \cdot x_{i}}, i=1,2, \ldots n$ are $R$-linear operators.

Definition: Higher order $q$-partial operator is defined by

$$
D_{q x_{i}^{m} x_{j}^{n}}^{m+n} f(x):=D_{q x_{i}^{m}}^{m}\left(D_{q x_{j}^{n}}^{n} f(x)\right)
$$

where

$$
D_{q \cdot x_{i}^{m} x_{j}^{n}}^{m+n}=D_{q \cdot x_{j}^{n} x_{i}^{m}}^{m+n}, m, n=0,1,2, \ldots
$$

Definition: Let $a=\left(a_{1}, a_{2}, \ldots, a_{n}\right) \in R^{n}$ be a arbitrary, but fixed and $f: D \subseteq R^{n} \rightarrow R$ be a continous. If $f$ has all the $q$ partial derivations at $a$, then the $q$-differential corresponding to $a$ is defined by

$$
d_{q} f(x, a)=\left(\left(x_{1}-a_{1}\right) \cdot D_{q \cdot x_{1}}+\left(x_{2}-a_{2}\right) \cdot D_{q \cdot x_{2}}+\ldots+\left(x_{n}-a_{n}\right) \cdot D_{q \cdot x_{n}}\right) f(a)
$$

and higher order the $q$-differential:

$$
\begin{aligned}
d_{q}^{(k)} f(x, a) & =\left(\left(x_{1}-a_{1}\right) \cdot D_{q \cdot x_{1}}+\left(x_{2}-a_{2}\right) D_{q \cdot x_{2}}+\ldots+\left(x_{n}-a_{n}\right) \cdot D_{q \cdot x_{n}}\right)^{(k)} f(a) \\
& =\underset{\substack{i_{1}+\ldots+i_{n}=k \\
i_{j} \in N}}{ }\left(\frac{[k]_{q} !}{\left[i_{1}\right]_{q} ! \cdot\left[i_{2}\right]_{q} ! \ldots .\left[i_{n}\right]_{q} !}\right) D_{q x_{1}, \ldots, x_{n}^{n}}^{k} f(a) \prod_{j=0}^{n}\left(x_{j}-a_{j}\right)^{\left(i_{j}\right)}
\end{aligned}
$$

Notice that a continous function $f(x)$ in a neighborhood of $a$ that does not include any point with a zero coordinate, has also continous $q$-partial derivatives.

Lemma: Let $f: D \subset R^{n} \rightarrow R$ be a function having all $q$-diferentials in some neighborhood of $a \in D$. Then $q$-Taylor expansion of $f$ at $a$ is given by [7] 


$$
f(x)=\sum_{k=0}^{\infty} \frac{d_{q}^{k} f(x, a)}{[k]_{q} !} .
$$

\section{Q-Taylor Linerization Method for Objectives}

In this section, we consider the MOLFP.

$$
\begin{aligned}
& \text { If } Z_{k}(x)=\frac{c_{k} x+\alpha_{k}}{d_{k} x+\beta_{k}}, k=1, \ldots, K, \text { then } \\
& \operatorname{Max} Z(x)=\left(Z_{1}(x), Z_{2}(x), \ldots, Z_{k}(x)\right), \\
& \text { s.t. } x \in S=\left\{x \mid A x\left(\begin{array}{l}
\leq \\
= \\
\geq
\end{array}\right) b, x \geq 0\right\}
\end{aligned}
$$

where $S, A, b$ and $x$ are as defined in problem (2.1), and $\forall x \in S, d_{k} x+\beta_{k}>0(\mathrm{k}=1, \ldots, \mathrm{K})$.

We will transform the model (2.16) to a new model obtained by the following three steps:

Step 1: Determine $x_{k}^{*}=\left(x_{k 1}^{*}, \ldots, x_{k n}^{*}\right)$ which is the value that is used to maximize the $k$ th objective function $Z_{k}(x)(k=1, \ldots, K)$ and $n$ is the number of the variables.

Step 2: Transform each objective functions by using first-order q-Taylor polynomial series as follows:

$$
\begin{aligned}
Z_{k}(x) & \cong L_{k}(x)=\sum_{m=0}^{1} \frac{d_{q}^{m} Z_{k}\left(x, x_{k}^{*}\right)}{[m]_{q} !}+O\left(h^{2}\right) \\
& =Z_{k}\left(x_{k}^{*}\right)+\left[\left(x_{1}-x_{k 1}^{*}\right) D_{q_{x_{1}}} Z_{k}\left(x_{k}^{*}\right)+\ldots+\left(x_{n}-x_{k n}^{*}\right) D_{q_{x_{n}}} Z_{k}\left(x_{k}^{*}\right)\right] \\
& =Z_{k}\left(x_{k}^{*}\right)+{ }_{j=1}^{n}\left(x_{j}-x_{k j}^{*}\right) D_{q x_{j}} Z_{k}\left(x_{k}^{*}\right)
\end{aligned}
$$

Step 3: Find satisfactory $x^{*}=\left(x_{1}^{*}, \ldots x_{n}^{*}\right)$ by solving the reduced problem to a single objective. MOLPP

Note that problem is solved by assuming that weights of the objective are equal. Thus, the problem (3.1) reduces the following

$$
\begin{aligned}
& \operatorname{Max} L(x)=\left(L_{1}(x), L_{2}(x), \ldots, L_{k}(x)\right), \\
& \text { s.t.: } x \in S=\left\{x \mid A x\left(\begin{array}{l}
\leq \\
= \\
\geq
\end{array}\right) b, x \geq 0\right\} .
\end{aligned}
$$

We assume that the weights of objective functions in problem (3.3) are equal, then the problem (3.3) is transformed to the following linear programming problem:

$$
\begin{aligned}
& \operatorname{Max} P(x)=\left(L_{1}(x)+L_{2}(x)+\ldots+L_{k}(x)\right), \\
& \text { s.t.: } x \in S=\left\{x \mid A x\left(\begin{array}{l}
\leq \\
= \\
\geq
\end{array}\right) b, x \geq 0\right\} .
\end{aligned}
$$


In problem (3.4), set $\mathrm{X}$ is non-empty convex set having feasible points. The optimal solution of problem (3.4) gives the efficient solution of MOLFPP (3.1).

\section{Numerical Example}

Example: We consider an example

$$
\begin{aligned}
\text { Maximize } Z_{1}(x) & =\frac{x_{1}+x_{2}-4}{6 x_{1}+x_{2}+3} \\
\text { Maximize } Z_{2}(x) & =\frac{x_{1}-x_{2}-5}{x_{2}+1} \\
\text { Maximize } Z_{3}(x) & =\frac{3 x_{1}+x_{2}-17}{-3 x_{1}+16} \\
-x_{1}+x_{2} & \leq 3 \\
x_{1}+x_{2} & \leq 7 \\
x_{1} & \leq 4 \\
x_{2} & \leq 4 \\
x_{1}, x_{2} & \geq 0
\end{aligned}
$$

It is observed that $Z_{1}<0, Z_{2}<0, Z_{3}<0$ for each $x$ in the feasible region. If the problem is solved for each of objectives one by one

$$
Z_{1}^{*}(1,4)=\frac{-1}{13}, \text { and } Z_{2}^{*}(4,1)=-1 \text { and } Z_{3}^{*}(4,3)=\frac{-1}{2} .
$$

Thus, we determine the first-order q-Taylor polynomial series (for $q=0.99$ ) for the objective functions $Z_{1}(x), Z_{2}(x)$ and $Z_{3}(x)$, then the following linearized forms of the objective functions are obtained:

$$
\begin{aligned}
& L_{1}(x) \cong Z_{1}(1,4)+\left[\left(x_{1}-1\right) D_{q x_{1}} Z_{1}(1,4)+\left(x_{2}-4\right) D_{q x_{2}} Z_{1}(1,4)\right] \\
& L_{2}(x) \cong Z_{2}(4,1)+\left[\left(x_{1}-4\right) D_{q x_{1}} Z_{2}(4,1)+\left(x_{2}-1\right) D_{q x_{2}} Z_{2}(4,1)\right] \\
& L_{3}(x) \cong Z_{3}(4,3)+\left[\left(x_{1}-4\right) D_{q x_{1}} Z_{3}(4,3)+\left(x_{2}-3\right) D_{q x_{2}} Z_{3}(4,3)\right]
\end{aligned}
$$

where from (2.8) and (2.9) are

$$
\begin{aligned}
& D_{q x_{1}} Z_{1}(1,4)=-0.041612174 \\
& D_{q x_{2}} Z_{1}(1,4)=0.083095917 \\
& D_{q x_{1}} Z_{2}(4,1)=0.254 \\
& D_{q x_{2}} Z_{2}(4,1)=0 \\
& D_{q x_{1}} Z_{3}(4,3)=0.36407767 \\
& D_{q x_{2}} Z_{3}(4,3)=0.25
\end{aligned}
$$

Thus we get

$$
\begin{aligned}
& L_{1}(x) \cong-0.041612174 x_{1}+0.083095917 x_{2}-0.3676945709 \\
& L_{2}(x) \cong 0.254 x_{1}-2 \\
& L_{3}(x) \cong 0.36407767 x_{1}+0.25 x_{2}-2.70631068
\end{aligned}
$$


and

$$
P(x)=L_{1}(x)+L_{2}(x)+L_{3}(x)=0.572465496 x_{1}+0.333095917 x_{2}-5.074005251
$$

Thus, the final form of the MOLFP problem is obtained as follows:

$$
\begin{aligned}
\text { Maximize } P(x) & \\
\text { Subject to } & -x_{1}+x_{2} \leq 3 \\
x_{1}+x_{2} & \leq 7 \\
x_{1} & \leq 4 \\
x_{2} & \leq 4 \\
x_{1}, x_{2} & \geq 0 .
\end{aligned}
$$

The problem is solved and the solution of the above problem is as follows:

$$
x_{1}=4, x_{2}=3 \text { and } Z_{1}(x)=-1 / 6, Z_{2}(x)=-1 \text { and } Z_{3}(x)=-1 / 2
$$

\section{Conclusions}

In this paper, we computed the solutions of MOLFPP using an efficient method which is based on $q$-calculus theories (in particular, first-order $q$-Taylor series). MOLFPP is reduced to MOLPP by first-order $q$-Taylor series. We assumed that the weights of the objective are equal. Then, the proposed solution method was applied to a numerical example to test the effect of first-order $q$-Taylor series method. The results show that the proposed method is more effective.

\section{References}

[1] Bitran G.R., Novaes A.G. (1973). Linear programming with a fractional objective function, Operation Research (21) $22-29$.

[2] Craven B.D. (1988). Fractional Programming, Heldermann Verlag, Berlin,

[3] Charnes A., Cooper W. (1962). Programming with linear fractional functions, Naval Research Logistics Quarterly (9) 181-186.

[4] Kac V., Cheung P. (2002). Quantum Calculus, Springer, New York,

[5] Kornbluth J.S.H., Steuer R.E. (1981). Multiple objective linear fractional programming, Management Science (27) 1024-1039.

[6] Nykowski I., Zolkiski Z. (1985). A compromise procedure for the multiple objective linear fractional programming problem, European Journal of Operational Research (19) 91-97.

[7] Rajkovic P.M., Stankovic M.S., Marinkovic S.D. (2003). On q-iterative methods for solving equations and systems. Novi Sad J.Math (33) $127-137$.

[8] Saad O. (2007). On stability of proper efficient solutions in multiobjective fractional programming problems under fuzziness, Mathematical and Computer Modelling (45) 221-231.

[9] M. Sakawa, K. Kato, Interactive decision-making for multiobjective linear fractional programming problems with block angular structure involving fuzzy numbers, Fuzzy Sets and Systems 97 (1988) 19--31. 